Review

\title{
Reducing Friction and Wear of Tribological Systems through Hybrid Tribofilm Consisting of Coating and Lubricants
}

\author{
Shuichiro Yazawa *, Ichiro Minami and Braham Prakash \\ Luleå University of Technology, Division of Machine Elements, 97187 Luleå, Sweden; \\ E-Mails: ichiro.minami@1tu.se (I.M.); braham.prakash@1tu.se (B.P.) \\ * Author to whom correspondence should be addressed; E-Mail: shuichiro.yazawa@ltu.se or \\ yazawashuichiro@gmail.com; Tel.: +46-920-491-855.
}

Received: 6 March 2014; in revised form: 8 April 2014 / Accepted: 17 April 2014 /

Published: 23 June 2014

\begin{abstract}
The role of surface protective additives becomes vital when operating conditions become severe and moving components operate in a boundary lubrication regime. After protecting film is slowly removed by rubbing, it can regenerate through the tribochemical reaction of the additives at the contact. However, there are limitations about the regeneration of the protecting film when additives are totally consumed. On the other hand, there are a lot of hard coatings to protect the steel surface from wear. These can enable the functioning of tribological systems, even in adverse lubrication conditions. However, hard coatings usually make the friction coefficient higher, because of their high interfacial shear strength. Amongst hard coatings, diamond-like carbon (DLC) is widely used, because of its relatively low friction and superior wear resistance. In practice, conventional lubricants that are essentially formulated for a steel/steel surface are still used for lubricating machine component surfaces provided with protective coatings, such as DLCs, despite the fact that the surface properties of coatings are quite different from those of steel. It is therefore important that the design of additive molecules and their interaction with coatings should be re-considered. The main aim of this paper is to discuss the DLC and the additive combination that enable tribofilm formation and effective lubrication of tribological systems.
\end{abstract}

Keywords: DLC; additive; boundary lubrication; coating-lubricant combination; lubrication mechanism 


\section{Nomenclature}

\begin{tabular}{|c|c|}
\hline Abbreviation & Details \\
\hline $\mathrm{a}-\mathrm{C}$ & Hydrogen-free amorphous carbon DLC \\
\hline $\mathrm{a}-\mathrm{C}: \mathrm{H}$ & Hydrogenated amorphous carbon DLC \\
\hline $\mathrm{a}-\mathrm{C}: \mathrm{H}: \mathrm{CrC}$ & Chromium carbide-doped hydrogenated amorphous carbon DLC \\
\hline a-C:H:Ti & Titanium-doped hydrogenated amorphous carbon DLC \\
\hline $\mathrm{a}-\mathrm{C}: \mathrm{H}: \mathrm{W}$ & Tungsten-doped hydrogenated amorphous carbon DLC \\
\hline $\mathrm{a}-\mathrm{C}: \mathrm{H}: \mathrm{WC}$ & Tungsten carbide-doped hydrogenated amorphous carbon DLC \\
\hline AP & Amine phosphate \\
\hline API & American Petroleum Institute \\
\hline AW & Anti-wear \\
\hline$[\mathrm{BMP}][\mathrm{FAP}]$ & $\begin{array}{l}\text { 1-Butyl-1-methylpyrrolidinium } \\
\text { tris(pentafluoroethyl)trifluorophosphate }\end{array}$ \\
\hline $\mathrm{BO}$ & Butyl oleate \\
\hline b-TPPT & Butylated triphenyl phosphorothionate \\
\hline $\mathrm{C}: \mathrm{H}: \mathrm{Ti}$ & Titanium-doped DLC \\
\hline $\mathrm{C}: \mathrm{H}: \mathrm{WC}$ & Tungsten carbide-doped hydrogenated DLC \\
\hline DLC & Diamond-like carbon \\
\hline $\mathrm{DLC}: \mathrm{Cr}$ & Chrome-doped DLC \\
\hline DLC:H & Hydrogenated DLC \\
\hline DLC:Si & Silicon-doped DLC \\
\hline DLC:W & Tungsten-doped DLC \\
\hline DLC:WC & Tungsten carbide-doped DLC \\
\hline EP & Extream pressure \\
\hline FM & Friction modifier \\
\hline g-DLC & Primarily $s p^{2}$ and hydrogen-free DLC \\
\hline GMO & Glycerol mono-oleate \\
\hline MoDTC & Molybdenum dithio-carbonate \\
\hline MT & Trinuclear molybdenum complex \\
\hline$[(\mathrm{NEMM}) \mathrm{MOE}][\mathrm{FAP}]$ & $\begin{array}{l}\text { Ethyl-dimethyl-2-methoxyethylammonium } \\
\text { tris(pentafluoroethyl)trifluorophosphate }\end{array}$ \\
\hline ODA & Octadecanoic acid \\
\hline PAO & Poly alpha-olefin \\
\hline PFA & Polycondensed fatty acid/ester \\
\hline PFPE & Perfluoropolyethers \\
\hline SIMS & Secondary Ion Mass Spectrometry \\
\hline SAE & Society of Automotive Engineers \\
\hline ta-C & Hydrogen-free tetrahedral amorphous carbon DLC \\
\hline ta-C:H & Hydrogenated tetrahedral amorphous carbon DLC \\
\hline ZnDTP & Zinc dithiophosphate \\
\hline
\end{tabular}

\section{Introduction}

Tribology is defined as "the science and technology of interacting surfaces in relative motion and of related subjects and practices" [1]. In the beginning of the 1960s, machine failures and breakdowns in plants occurred frequently. Careful analysis of these cases revealed that these troubles mostly arose 
because of high friction and wear due to poor lubrication. Under such circumstances, the British Department of Education and Science set up a working group to look into industrial problems caused by friction and wear. The working group used the term "tribology" in the final report, called the Jost Report, published in 1966 [2].

After the new term was coined, wear, friction and lubrication were studied as an interdisciplinary field, i.e., tribology. Tribology has great potential to contribute toward saving materials and energy resources. The reduction of friction contributes to the reduction of energy loss by heat. The reduction of wear can prolong the lifetime of machine components. Lubrication is one of the most important aspects of tribology, because of its role in reducing the friction between the pair of contacting surfaces and protecting them from the wear. To fulfill this requirement, the lubricants separate the pair of relatively moving surfaces through the formation of a lubricant film [3].

It has been well established that lubrication modes fall into three categories, which are hydrodynamic lubrication, mixed lubrication and boundary lubrication, as expressed by the Stribeck curve in Figure 1. When the Hersey number $(\eta v / p$ : where $\eta$ is viscosity of lubricant, $v$ is velocity of surface and $p$ is pressure) is high, a hydrodynamic lubrication regime occurs. A pair of tribo-surfaces is separated by a sufficiently thick liquid film in a hydrodynamic lubrication regime. Usually, machines are designed to operate in this regime, since low friction, as well as low wear are achieved. When the Hersey number is small, the lubrication regime changes to a boundary regime. Surfaces come into contact with each other. As a result, high friction and wear are observed. A mixed lubrication regime is an intermediate regime between hydrodynamic lubrication and boundary lubrication.

Figure 1. Stribeck curve.

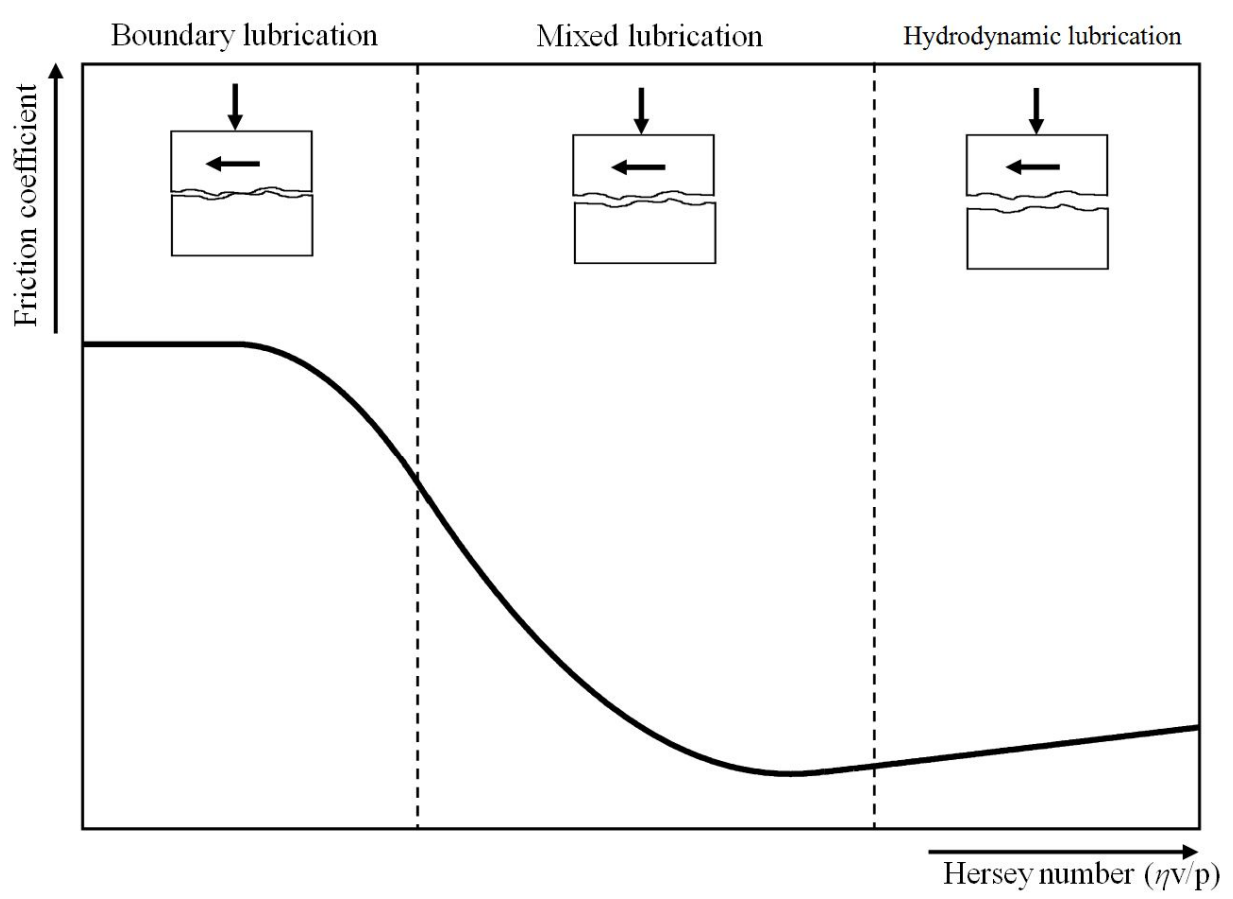

As the demands for high performance on machines and systems increase, the lubrication condition of a surface gets more severe. High operating temperatures and contact stresses, particularly at low speeds, cause severe lubrication conditions. A boundary lubrication regime occurs during running-in, starting/stopping and load changing periods. Improving the rheological properties of the base oil could 
be one of the solutions. However, there are limitations to solving the problem by base oil only, and the role of additives become important.

A friction modifier reduces friction in a light-load mixed lubrication regime [4,5]. The friction modifier interacts with the surface through adsorption. However, the friction modifier on the surface tends to desorb when the tribological condition becomes harsh. Then, an anti-wear additive is required in the boundary lubrication regime. An anti-wear additive can develop a protective film on a steel surface through tribochemical reactions.

The additive technology at present is well established for manufacturing industrial lubricants, automobile lubricants, hydraulic fluids and other lubricants. Especially, ZnDTP and MoDTC additives for a steel/steel friction surface are well studied and commercialized [6,7].

Although the protecting film is slowly removed by rubbing, it can regenerate by the tribochemical reaction. In forming a new film, the additive and steel from the interacting surfaces are consumed. When additives are totally consumed, new film cannot be formed any more. To extend the oil life, additional additives are needed. However, change of properties in AW (anti-wear) additive is caused by oxidation. To prevent oxidation, addition of antioxidant is required [8]. What is worse is that too much AW additive causes more wear on steel surfaces than without any AW additives [9].

The modification and changes to reduce the environmental damage are one of the principles for green chemistry [10]. Therefore, simplifying the contents of lubricants is the primary issues for emerging "greener" lubricants. It is reported that ZnDTP causes acute toxicity [11], reduces the catalyst effectiveness and blocks exhaust filters [12]. Therefore, the reduction of heavy elements is an option to make conventional additives "greener". Organic FM (friction modifier) is a greener candidate in terms of heavy element-free additives. It is reported that low friction is achieved by the glycerol mono-oleate and DLC combination [13]. It is reported that GMO interacts with DLC, and a boundary film consisting of GMO and PAO was formed [14].

On the other hand, there are a lot of hard coatings to protect steel surfaces from wear, such as $\mathrm{TiO}_{2}$, $\mathrm{Al}_{2} \mathrm{O}_{3}$ and $\mathrm{CrN}$. In general, hard coatings make the friction coefficient higher, because of their high interfacial shear strengths $[15,16]$. Among the hard coatings, DLC is becoming quite widely used, because of its low friction, superior wear resistance and simple composition (only $\mathrm{C}$ and $\mathrm{H}$ ) $[17,18]$. DLC can be applied to machine component surfaces operating in dry, as well as lubricated conditions [16]. When DLC is applied to machine component surfaces operating in lubricated systems, conventional lubricants formulated for a steel/steel surface are still used for DLC coated surfaces. The surface properties (e.g., surface energy) of these coatings are quite different from those of steel. Therefore, the interaction of additive molecules should be re-considered.

\section{Hybrid Lubrication Concept}

Conventional tribofilm and hard coating on steel surfaces, respectively, have both advantages and drawbacks as shown in Figure 2 [19]. To overcome the disadvantages and to achieve low friction and low wear simultaneously, forming simplified tribofilm on the hard coating would be desirable.

However, hybrid tribofilm consisting of tribofilm and the hard coating has another disadvantage. The disadvantage is the difficulty of tribofilm formation on the hard coating, because the hard coatings possess less reactivity to the lubricant additives compared to a steel surface. The hybrid tribofilm has 
the potential to achieve low friction and low wear simultaneously, and to achieve this, a suitable method for forming tribofilm on a hard coating is needed.

This paper aims at surveying and discussing the type of DLC and additive combinations that promote the formation of tribofilm. Furthermore, the possibility of achieving low friction and low wear simultaneously through tribofilm formation on a hard coating will be discussed.

Figure 2. Strategy of this paper.
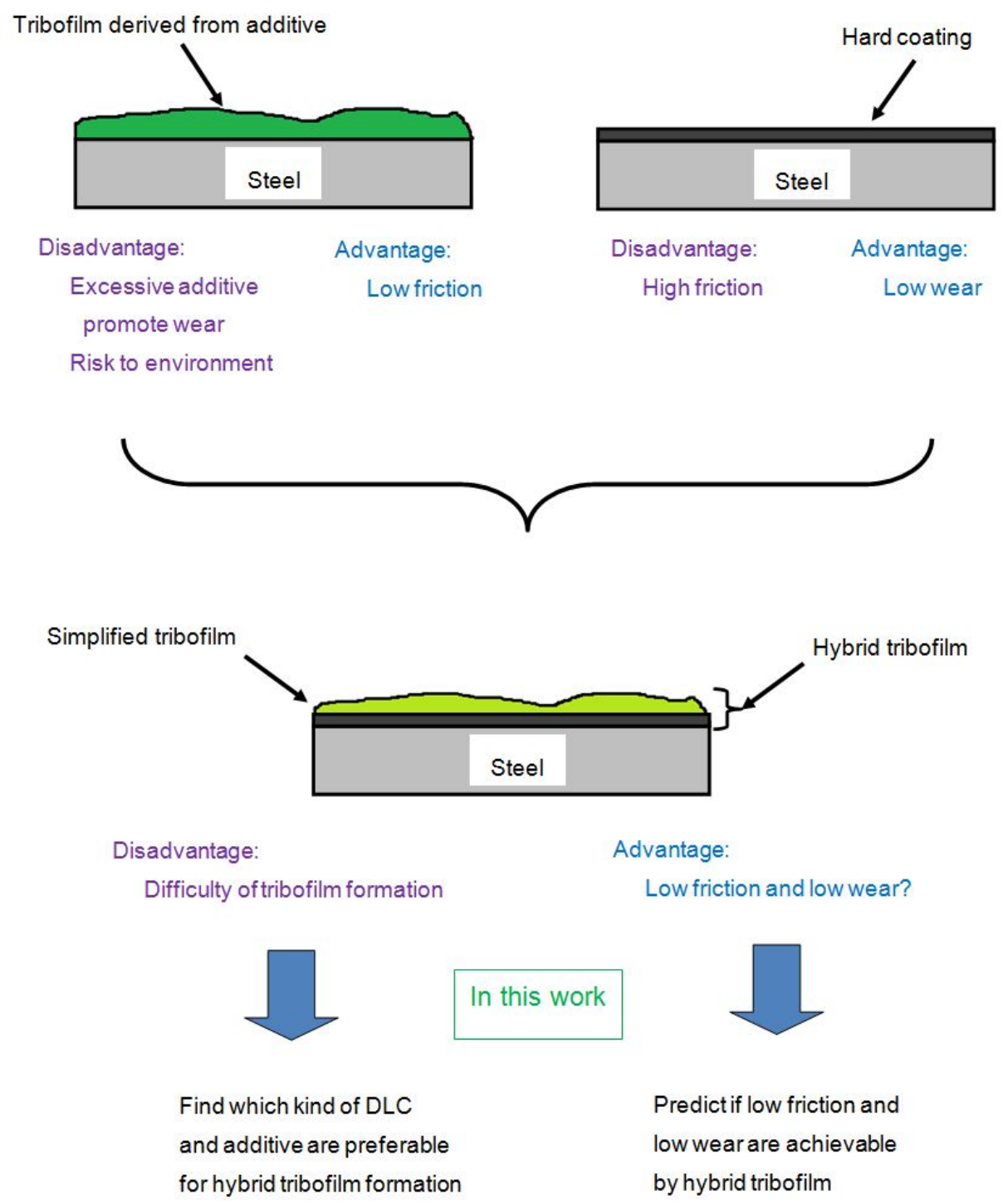

\section{Reference Survey}

\subsection{Effect of DLC Coatings and Lubricants on Tribofilm Formation}

Among a lot of papers related to tribology, the papers that focus on a combination of DLC coatings and additives in lubricants are listed in the tables below. Information about the type of DLC coatings, the type of lubricants and remarks about tribofilm have been summarized.

Table 1 shows tribofilm formation on DLC coatings with ZnDTP. It was reported that ZnDTP pads form only on the $18 \% \mathrm{~W}$-containing a-C:H:W coating [20]. If the $\mathrm{W}$ content is higher, ZnDTP pad formation is disrupted by graphitization of the DLC coatings. 
Table 1. Tribofilm formation on DLC coatings from $\mathrm{ZnDTP}$.

\begin{tabular}{|c|c|c|c|c|}
\hline $\begin{array}{c}\text { DLC coatings } \\
\text { (See Nomenclature) }\end{array}$ & $\begin{array}{c}\text { Lubricants } \\
\text { (See Nomenclature) }\end{array}$ & Remarks about tribofilm & Analysis & Reference \\
\hline $\begin{array}{l}\text { a-C, } \\
\text { a-C:H, } \\
\mathrm{a}-\mathrm{C}: \mathrm{H}: \mathrm{W}\end{array}$ & $\begin{array}{l}\text { API (American } \\
\text { Petroleum Institute) } \\
\text { Group III oil, ZnDTP }\end{array}$ & $\begin{array}{l}\text { Formation of tribofilm = detected: } \\
\text { The formation of ZnDTP-derived tribofilms on all DLC surfaces is clearly evident and } \\
\text { has been demonstrated by means of SEM, EDX and AFM. However, ZnDTP pads } \\
\text { form only on the } 18 \% \mathrm{~W} \text {-containing a-C:H:W coating, whereas for higher W\% } \\
\text { a-C:H:W coatings, graphitization appears to disrupt pad formation. }\end{array}$ & $\begin{array}{l}\text { SEM, } \\
\text { EDX, } \\
\text { AFM }\end{array}$ & [20] \\
\hline $\begin{array}{l}\text { a-C, a-C:H, } \\
\text { ta-C, } \\
\text { DLC:W, } \\
\text { DLC:WC, } \\
\text { DLC:Si }\end{array}$ & $\begin{array}{c}\text { API Group III oil, } \\
\text { ZnDTP }\end{array}$ & $\begin{array}{l}\text { Formation of tribofilm = detected: } \\
\text { The formation of ZnDTP-derived tribofilms on all DLC surfaces is clearly evident and } \\
\text { has been demonstrated by means of SEM, EDX, ToF-SIMS (Secondary Ion Mass } \\
\text { Spectrometry) and AFM. However, ZnDTP pads form only on DLC:W. }\end{array}$ & $\begin{array}{l}\text { SEM, } \\
\text { EDX, } \\
\text { ToF-SIMS, } \\
\text { AFM }\end{array}$ & [21] \\
\hline $\begin{array}{l}\mathrm{a}-\mathrm{C} \\
\mathrm{a}-\mathrm{C}: \mathrm{H} \\
\mathrm{C}: \mathrm{H}: \mathrm{Ti}\end{array}$ & $\begin{array}{l}\text { PAO, } \\
\text { ZnDTP, } \\
\text { MoDTC }\end{array}$ & $\begin{array}{l}\text { Formation of tribofilm = detected: } \\
\text { MoDTC and ZnDTP additives react directly on amorphous carbon surfaces. They } \\
\text { seem to be more active with selected hydrogenated amorphous carbon surfaces. } \\
\text { Performance of tribofilm = positive: } \\
\text { The friction and wear performances are improved by coating both counter faces. } \\
\text { Morphology of tribofilm: } \\
\text { XPS analysis shows the formation of } \mathrm{MoS}_{2} \text { in the contact area only. } \\
\text { Additive interactions: } \\
\text { On amorphous carbon surfaces, the role of the antiwear ZnDTP agent seems to be } \\
\text { principally to enhance the formation of } \mathrm{MoS}_{2} \text { sheets. } \\
\text { Chemical property of tribofilm: } \\
\text { The presence of zinc phosphate has been detected by EDX in the wear debris collected } \\
\text { inside the tribofilm. } \\
\text { The composition of tribofilm appears similar to that of tribofilm obtained on steel } \\
\text { surfaces in the same lubrication conditions. Tribochemical reactions can occur without } \\
\text { the presence of an iron catalyst element in the tribo-system. }\end{array}$ & $\begin{array}{l}\text { XPS, } \\
\text { EDX }\end{array}$ & [22] \\
\hline
\end{tabular}


Table 1. Cont.

\begin{tabular}{|c|c|c|c|c|}
\hline & & Formation of tribofilm $=$ detected: & & \\
\hline ta-C & $\begin{array}{c}\text { PAO, } \\
\text { ZnDTP, } \\
\text { GMO }\end{array}$ & $\begin{array}{l}\text { A white distributed ZnDTP-derived tribofilm was formed on ta-C surfaces in the } \\
\text { PAO + ZnDTP lubricant. } \\
\text { Performance of tribofilm = negative: } \\
\text { Tribofilm does not provide wear protection. } \\
\text { Additive interactions: } \\
\text { FESEM and AFM analyses showed that ZnDTP-derived pad-like tribofilm did not form on the } \\
\text { steel surface when lubricated with PAO + GMO + ZnDTP oil. It is believed that GMO may } \\
\text { suppress the ZnDTP and, thus, prohibit the formation of ZnDTP tribofilm. }\end{array}$ & $\begin{array}{c}\text { FESEM, } \\
\text { AFM }\end{array}$ & {$[23]$} \\
\hline $\mathrm{a}-\mathrm{C}: \mathrm{H}$ & $\begin{array}{c}\text { PAO, } \\
\text { ZnDTP }\end{array}$ & $\begin{array}{l}\text { Formation of tribofilm = detected: } \\
\text { The formation of a tribofilm by ZnDTP in PAO on both DLC and steel (self-mated) surfaces } \\
\text { was demonstrated by means of SEM, EDX and ToF-SIMS. This showed that the film could be } \\
\text { formed under very low wear conditions in the absence of iron. } \\
\text { Morphology of tribofilm: } \\
\text { It was seen from the AFM images that the tribofilm on the DLC surfaces had a different } \\
\text { structure from that found on steel surfaces. } \\
\text { Performance of tribofilm = negative: } \\
\text { After washing the sample in an ultrasonic bath with cyclohexane, the tribofilm on DLC could } \\
\text { no longer be observed. This indicates that the adhesion of the tribofilm to the DLC surface is } \\
\text { much weaker than that of the tribofilm to steel. }\end{array}$ & $\begin{array}{c}\text { SEM, } \\
\text { EDX, } \\
\text { ToF-SIMS, } \\
\text { AFM }\end{array}$ & {$[24]$} \\
\hline
\end{tabular}


Table 1. Cont

\begin{tabular}{|c|c|c|c|c|}
\hline ta-C & $\begin{array}{c}\text { PAO, } \\
\text { ZnDTP, } \\
\text { GMO }\end{array}$ & $\begin{array}{l}\text { Formation of tribofilm }=\text { detected: } \\
\text { Performance of tribofilm = negative: } \\
\text { Relatively high friction is attributed to the formation of pad-like tribofilm, both on ta-C and } \\
\text { steel surfaces for DLC/steel combination. } \\
\text { No additional friction reduction or no ZnDTP-derived wear protective tribofilm formations } \\
\text { are recorded under PAO + GMO + ZnDTP lubricated conditions for DLC/steel and } \\
\text { DLC/DLC combinations. } \\
\text { Performance of tribofilm = positive: } \\
\text { On the other hand, formation of ZnDTP-derived thin white layer on ta-C DLC generates the } \\
\text { lowest friction for DLC/DLC contact. }\end{array}$ & $\begin{array}{c}\text { Fe-SEM, } \\
\text { AFM }\end{array}$ & {$[25]$} \\
\hline $\mathrm{a}-\mathrm{C}: \mathrm{H}$ & $\begin{array}{c}\text { PAO, } \\
\text { ZnDTP, } \\
\text { b-TPPT, AP }\end{array}$ & $\begin{array}{l}\text { Formation of tribofilm = detected: } \\
\text { ZnDTP and b-TPPT showed a similar tribological behavior for steel/steel and DLC/DLC } \\
\text { contacts. Both built up similar pad-like structures on steel and a tribofilm was also formed on } \\
\text { DLC for the two cases, while no AP film was observed on DLC with AFM, although } \\
\text { ToF-SIMS confirmed the presence of the physisorbed and chemisorbed additive on the surface. } \\
\text { Performance of tribofilm = negative: } \\
\text { The weaker adhesion of the ZnDTP tribofilm built up on DLC compared with that built up on } \\
\text { steel was confirmed with scratch tests and can be explained by the inertness of the DLC coating } \\
\text { preventing the reaction with the DLC surface. }\end{array}$ & $\begin{array}{c}\text { AFM, } \\
\text { ToF-SIMS }\end{array}$ & [26] \\
\hline $\begin{array}{c}\mathrm{a}-\mathrm{C}: \mathrm{H}, \\
\mathrm{a}-\mathrm{C}: \mathrm{H}: \mathrm{W}, \\
\mathrm{a}-\mathrm{C}: \mathrm{H}: \mathrm{WC}, \\
\text { ta-C, } \\
\text { DLC:Si }\end{array}$ & $\begin{array}{l}\text { API Group III } \\
\text { oil, ZnDTP }\end{array}$ & $\begin{array}{l}\text { Formation of tribofilm = detected: } \\
\text { Chemical property of tribofilm: } \\
\text { The use of ToF-SIMS to study pre-formed ZnDTP tribofilms before and after rubbing in base } \\
\text { oil indicates that rubbing in base oil results in almost complete loss of sulfur species, both } \\
\text { sulfide and thiophosphate from the film. } \\
\text { Performance of tribofilm = negative: } \\
\text { This suggests both that these materials are normally present in the outermost part of ZnDTP } \\
\text { films and that they are relatively weakly bound and lost during rubbing. }\end{array}$ & $\begin{array}{c}\text { AFM, } \\
\text { ToF-SIMS }\end{array}$ & [27] \\
\hline
\end{tabular}


Table 1. Cont

\begin{tabular}{|c|c|c|c|c|}
\hline DLC & $\begin{array}{l}\text { PAO, } \\
\text { ZnDTP, } \\
\text { MoDTC }\end{array}$ & $\begin{array}{l}\text { Formation of tribofilm }=\text { detected: } \\
\text { Chemical property of tribofilm: } \\
\mathrm{Zn} \text { phosphate was absorbed on DLC surface. } \mathrm{MoO}_{3} \text { and } \mathrm{MoS}_{2} \text { were not absorbed on } \\
\text { the DLC surface. }\end{array}$ & $\begin{array}{c}\text { XANES, } \\
\text { XPS }\end{array}$ & [28] \\
\hline $\mathrm{a}-\mathrm{C}$ & $\begin{array}{l}\text { PAO, } \\
\text { ZnDTP, } \\
\text { MoDTC, } \\
\text { MT }\end{array}$ & $\begin{array}{l}\text { Formation of tribofilm = detected: } \\
\text { Additive interactions: } \\
\text { The antiwear tribofilm composed of zinc phosphate was detected at the a-C/CI interface when } \\
\text { ZnDTP was used alone. The performance of ZnDTP had to be compromised when it was used } \\
\text { with MoDTC or Moly Trimer. }\end{array}$ & $\begin{array}{l}\text { SEM, } \\
\text { AFM, } \\
\text { XPS }\end{array}$ & [29] \\
\hline $\mathrm{a}-\mathrm{C}: \mathrm{H}$ & $\begin{array}{l}\text { PAO, } \\
\text { ZnDTP, } \\
\text { MoDTC }\end{array}$ & $\begin{array}{l}\text { Formation of tribofilm }=\text { detected: } \\
\text { Chemical property of tribofilm: } \\
\text { ZnDTP decomposed under boundary lubrication condition and formed } \mathrm{Zn} \text {-phosphate/ZnS/ZnO } \\
\text { anti-wear species in the tribofilms formed on a-C:H. }\end{array}$ & $\begin{array}{c}\text { SEM, } \\
\text { XPS }\end{array}$ & [30] \\
\hline DLC:WC & $\begin{array}{l}\text { PAO, } \\
\text { ZnDTP, } \\
\text { Alkyl } \\
\text { thiadiazole }\end{array}$ & $\begin{array}{l}\text { Formation of tribofilm = not detected: } \\
\text { In the current study, ZnDTP did not form P-containing tribofilms on any of the fully-coated } \\
\text { tested systems, indicating that the antiwear mechanism of this additive cannot be attributed to } \\
\text { the formation of phosphate glass tribofilm. }\end{array}$ & XPS & [31] \\
\hline DLC:H & $\begin{array}{l}\text { PAO, } \\
\text { ZnDTP, } \\
\text { MoDTC }\end{array}$ & $\begin{array}{l}\text { Formation of tribofilm = not detected: } \\
\text { The appearance of C-1's peak after } 240 \mathrm{~s} \text { indicated that no tribofilm was left, and the X-ray } \\
\text { beam reached the surface of the pure DLC:H coating. }\end{array}$ & XPS & [32] \\
\hline $\mathrm{a}-\mathrm{C}: \mathrm{H}$ & $\begin{array}{l}\text { SAE } 5 \mathrm{~W}-30 \\
\text { 5W-20, } \\
\text { ZnDTP, } \\
\text { MoDTC }\end{array}$ & $\begin{array}{l}\text { Formation of tribofilm }=\text { not detected: } \\
\text { A tribofilm did not form on the DLC-coated disc due to the inactive chemical } \\
\text { properties of DLC. }\end{array}$ & XPS & [33] \\
\hline DLC & $\begin{array}{l}\text { PAO, } \\
\text { ZnDTP, } \\
\text { MoDTC }\end{array}$ & $\begin{array}{l}\text { Formation of tribofilm }=\text { not detected: } \\
\text { The presence of an additive-derived tribofilm on the DLC surface, as evidenced by the XPS } \\
\text { study, confirmed that the boundary lubrication between the cam and follower resulted in the } \\
\text { decomposition of additives. }\end{array}$ & XPS & [34] \\
\hline
\end{tabular}


It is also reported that ZnDTP pads were formed only on DLC:W; however, the wear of DLC:W is large if ZnDTP is not used [21]. Therefore, DLC:W should be combined with ZnDTP. On the other hand, ZnDTP pads were not formed on DLC:WC [21,31]. Because DLC are chemically inert, doping a highly reactive material with ZnDTP, such as tungsten, seems to be effective for tribofilm formation.

It is reported that GMO may suppress the interaction of $\mathrm{ZnDTP}$ with surface and, thus, prohibit the formation of ZnDTP tribofilm [23]. Additive interactions should be taken care of for tribofilm formation on DLC.

Although ZnDTP-derived film formation was reported by several documents, the adhesion of the tribofilm to the DLC surface is much weaker than that to the steel surface [24]. The weaker adhesion of the ZnDTP tribofilm formed on DLC compared to that on steel was confirmed with scratch tests and can be explained by the inertness of the DLC coating which cannot react with ZnDTP surface [26]. Especially, materials normally present in the outermost part of ZnDTP films are relatively weakly bound and lost during rubbing [27].

Table 2 shows tribofilm formation on DLC coatings with MoDTC. It is reported that additive interactions affect film formation. ZnDTP principally enhances the formation of $\mathrm{MoS}_{2}$ sheets [22]. The reported mechanism was that sulfur atoms provided from ZnDTP help molybdenum oxysulfide change to $\mathrm{MoS}_{2}$.

Table 2. Tribofilm formation on DLC coatings from MoDTC.

\begin{tabular}{|c|c|c|c|c|}
\hline $\begin{array}{l}\text { DLC coatings } \\
\text { (See } \\
\text { Nomenclature) }\end{array}$ & $\begin{array}{c}\text { Lubricants } \\
\text { (See } \\
\text { Nomenclature) }\end{array}$ & Remarks about tribofilm formation & Analysis & Reference \\
\hline $\begin{array}{c}\text { a-C, } \\
\text { a-C:H, } \\
\text { C:H:Ti }\end{array}$ & $\begin{array}{c}\text { PAO, ZnDTP } \\
\text { MoDTC }\end{array}$ & $\begin{array}{l}\text { Formation of tribofilm = detected: } \\
\text { MoDTC and ZnDTP additives react directly on } \\
\text { amorphous carbon surfaces. They seem to be more } \\
\text { active with selected hydrogenated amorphous carbon } \\
\text { surfaces. } \\
\text { Performance of tribofilm = positive: } \\
\text { The friction and wear performances are improved by } \\
\text { coating both counter faces. } \\
\text { Morphology of tribofilm: } \\
\text { XPS analysis shows the formation of } \text { MoS }_{2} \text { in the } \\
\text { contact area only. } \\
\text { Additive interactions: } \\
\text { On amorphous carbon surfaces, the role of the antiwear } \\
\text { ZnDTP agent seems to be principally to enhance the } \\
\text { formation of MoS }{ }_{2} \text { sheets. } \\
\text { Chemical property of tribofilm: } \\
\text { The presence of zinc phosphate has been detected by } \\
\text { EDX in the wear debris embedded in the tribofilm. } \\
\text { The composition of tribofilm appears similar to that of } \\
\text { tribofilm obtained on steel surfaces in the same } \\
\text { lubrication conditions. Tribochemical reactions can } \\
\text { occur without the presence of an iron catalyst element } \\
\text { in the tribo-system. }\end{array}$ & $\begin{array}{l}\text { XPS, } \\
\text { EDX }\end{array}$ & [22] \\
\hline
\end{tabular}


Table 2. Cont.

\begin{tabular}{|c|c|c|c|c|}
\hline $\begin{array}{l}\text { a-C:H, } \\
\text { g-DLC }\end{array}$ & $\begin{array}{c}\text { API Group } \\
\text { II oil, } \\
\text { ZnDTP, } \\
\text { MoDTC, GMO, } \\
\text { PFA, } \\
\text { Amine }\end{array}$ & $\begin{array}{l}\text { Formation of tribofilm = detected: } \\
\text { MoDTC clearly forms a friction-reducing film on } \\
\text { a-C:H. } \\
\text { Morphology of tribofilm: } \\
\text { This film takes the form of rows of tiny pads, } \\
\text { a few nanometers high, each pad showing low } \\
\text { lateral force. These pads are not oriented along the } \\
\text { sliding direction, but follow the topographic } \\
\text { morphology features of the coating, which are } \\
\text { oriented perpendicular to the sliding direction. } \\
\text { Chemical property of tribofilm: } \\
\text { These low friction regions are characteristic of the } \\
\text { friction response of MoDTC and are almost } \\
\text { certainly nanocrystallites of MoS } \mathrm{S}_{2} \text { formed from } \\
\text { MoDTC by a tribochemical reaction. } \\
\text { Mechanism of formation of tribofilms } \\
\text { Such pads are normally found to form only on } \\
\text { asperity peaks, where their generation is believed to } \\
\text { be stimulated by solid-solid rubbing. }\end{array}$ & AFM & [35] \\
\hline $\begin{array}{l}\text { a-C, } \\
\text { a-C:H, } \\
\text { a-C:H:W, } \\
\text { a-C:H:WC, } \\
\text { ta-C, } \\
\text { ta-C:H, } \\
\text { DLC:Si }\end{array}$ & $\begin{array}{l}\text { API Group } \\
\text { III oil, } \\
\text { MoDTC }\end{array}$ & $\begin{array}{l}\text { Formation of tribofilm = detected: } \\
\text { The formation of MoDTC-derived tribofilms on all } \\
\text { DLC surfaces was clearly evident and was } \\
\text { demonstrated by means of SEM, EDX, ToF-SIMS } \\
\text { and AFM. } \\
\text { Performance of tribofilm = positive: } \\
\text { With MoDTC, all DLCs showed reduced boundary } \\
\text { friction, and in particular, W-containing DLCs } \\
\text { showed low boundary friction, because of the } \\
\text { formation of } \mathrm{WS}_{2} \text { and Mo-derived tribolayers on } \\
\text { the surface. }\end{array}$ & $\begin{array}{c}\text { SEM, EDX, } \\
\text { ToF-SIMS, } \\
\text { AFM }\end{array}$ & [36] \\
\hline a-C:H:W & $\begin{array}{l}\text { PAO, } \\
\text { GMO, } \\
\text { ZnDTP, } \\
\text { MoDTC }\end{array}$ & $\begin{array}{l}\text { Formation of tribofilm = detected: } \\
\text { Chemical property of tribofilm: } \\
\text { Friction reduction is contributed by both formation } \\
\text { of } \mathrm{MoS}_{2} \text { and surface graphitization. The formation } \\
\text { of } \mathrm{MoS}_{2} \text { by chemical decomposition from MoDTC } \\
\text { is dominant rather than the possible formation } \\
\text { of } \mathrm{WS}_{2} \text {. }\end{array}$ & $\begin{array}{c}\text { AFM, } \\
\text { optical } \\
\text { microscope }\end{array}$ & [37] \\
\hline
\end{tabular}


Table 2. Cont.

\begin{tabular}{|c|c|c|c|c|}
\hline DLC & $\begin{array}{l}\text { PAO, } \\
\text { ZnDTP, } \\
\text { MoDTC, } \\
\text { T307 }\end{array}$ & $\begin{array}{l}\text { Formation of tribofilm = detected: } \\
\text { Performance of tribofilm = positive: } \\
\text { The introduction of MoDTC into PAO-4 is } \\
\text { beneficial for reducing the friction coefficients of } \\
\text { DLC coatings; however, it simultaneously } \\
\text { decreases the wear resistance of the coatings. The } \\
\text { friction coefficients and wear rates of DLC coatings } \\
\text { lubricated with PAO-4 can be reduced by the } \\
\text { addition of ZnDTP in PAO- } 4 \text {. The addition of T307 } \\
\text { in PAO-4 improves the wear resistance of DLC } \\
\text { coatings; however, it has a negligible effect on the } \\
\text { friction coefficients of the coatings. }\end{array}$ & SEM & {$[38]$} \\
\hline DLC:W & $\begin{array}{c}\text { PAO, } \\
\text { MoDTC }\end{array}$ & $\begin{array}{l}\text { Formation of tribofilm }=\text { detected: } \\
\text { Chemical property of tribofilm: } \\
\text { The improved tribological properties of the } \\
\text { sulfurized DLC:W coating lubricated with MoDTC } \\
\text { are mainly due to the formation of } \mathrm{WS}_{x} \text { and the } \\
\text { higher ratio of Mo sulfide/Mo oxide and } s p^{2} / s p^{3} \text { in } \\
\text { the tribofilm. }\end{array}$ & $\begin{array}{c}\text { SEM, } \\
\text { XPS }\end{array}$ & [39] \\
\hline $\mathrm{a}-\mathrm{C}: \mathrm{H}: \mathrm{CrC}$ & MoDTC & $\begin{array}{l}\text { Formation of tribofilm = detected: } \\
\text { A tribolayer formed from the additives is only } \\
\text { deposited in the loaded areas of the friction track } \\
\text { and not in the unloaded environment of the coating. }\end{array}$ & $\begin{array}{l}\text { SEM, } \\
\text { EDX }\end{array}$ & {$[40]$} \\
\hline DLC:H & $\begin{array}{l}\text { PAO, } \\
\text { ZnDTP, } \\
\text { MoDTC }\end{array}$ & $\begin{array}{l}\text { Formation of tribofilm = not detected: } \\
\text { The appearance of C-1's peak after } 240 \mathrm{~s} \text { indicated } \\
\text { that no tribofilm was left and the X-ray beam } \\
\text { reached the surface of the pure DLC:H coating. }\end{array}$ & XPS & [32] \\
\hline $\mathrm{a}-\mathrm{C}: \mathrm{H}$ & $\begin{array}{l}\text { SAE } 5 \mathrm{~W}-30 \\
\text { SAE } 5 \mathrm{~W}-20 \\
\text { ZnDTP, } \\
\text { MoDTC }\end{array}$ & $\begin{array}{l}\text { Formation of tribofilm = not detected: } \\
\text { A tribofilm did not form on the DLC-coated disc, } \\
\text { due to the inactive chemical properties of DLC. }\end{array}$ & XPS & [33] \\
\hline DLC & $\begin{array}{l}\text { PAO, } \\
\text { ZnDTP, } \\
\text { MoDTC }\end{array}$ & $\begin{array}{l}\text { Formation of tribofilm = not detected: } \\
\text { The presence of an additive-derived tribofilm on the } \\
\text { DLC surface, as evidenced by the XPS study, } \\
\text { confirmed that the boundary lubrication between } \\
\text { cam and follower resulted in the decomposition } \\
\text { of additives. }\end{array}$ & XPS & [34] \\
\hline
\end{tabular}


Table 2. Cont.

\begin{tabular}{|c|c|c|c|c|}
\hline DLC:H & $\begin{array}{l}\text { Two } \\
\text { synthesized } \\
\text { engine oil, } \\
\text { MoDTC }\end{array}$ & $\begin{array}{l}\text { Formation of tribofilm = not detected: } \\
\text { It was remarkable that the molybdenum compounds } \\
\text { were not observed on the DLC surface. }\end{array}$ & $\begin{array}{l}\text { SEM, } \\
\text { EDX }\end{array}$ & [41] \\
\hline $\mathrm{a}-\mathrm{C}: \mathrm{H}$ & $\begin{array}{l}\text { Fully } \\
\text { formulated oil, } \\
\text { ZnDTP, } \\
\text { MoDTC }\end{array}$ & $\begin{array}{l}\text { Formation of tribofilm = not detected: } \\
\text { Formation of } \mathrm{MoS}_{2} \text {, which is responsible for } \\
\text { providing lower friction, was mainly dominant in } \\
\text { the tribofilm formed on the counterpart (cast iron } \\
\text { pin) from high concentration Mo-FM-containing } \\
\text { fully-formulated oils, while the amount of Mo } \\
\text { formed on the DLC wear scar was negligible. }\end{array}$ & $\begin{array}{c}\text { SEM, } \\
\text { XPS }\end{array}$ & [42] \\
\hline
\end{tabular}

MoDTC clearly forms friction-reducing tiny pads [35]. They are normally found to form only on asperity tips, where their generation is believed to be stimulated by solid-solid rubbing. Particularly, $\mathrm{W}$-containing DLCs showed low boundary friction, because of the formation of $\mathrm{WS}_{2}$ and Mo-derived tribolayers on the surface. Doping a reactive material, such as tungsten, with MoDTC seems to be effective for the tribofilm formation.

On the other hand, MoDTC has negative tribological effects in some cases. One is MoDTC causes graphitization of DLC surface [41]. Graphitization of DLC accelerates wear. The other is the generation of $\mathrm{MoO}_{3}$ from $\mathrm{MoDTC}$. $\mathrm{MoO}_{3}$ makes the DLC coating brittle. Finally, high wear is caused by the brittle surface [42].

Table 3 shows tribofilm formation on DLC coatings with GMO. Thin tribofilm, which is less than $2 \mathrm{~nm}$ thick, is indicated by SIMS analysis [13].

Table 3. Tribofilm formation on DLC coatings from GMO.

\begin{tabular}{|c|c|c|c|c|}
\hline $\begin{array}{l}\text { DLC coatings } \\
\text { (See } \\
\text { Nomenclature) } \\
\end{array}$ & $\begin{array}{c}\text { Lubricants } \\
\text { (See } \\
\text { Nomenclature) } \\
\end{array}$ & Remarks about tribofilm formation & Analysis & Reference \\
\hline $\begin{array}{c}\mathrm{a}-\mathrm{C}: \mathrm{H} \\
\text { ta-C }\end{array}$ & $\begin{array}{l}\text { PAO, } \\
\text { GMO }\end{array}$ & $\begin{array}{l}\text { Formation of tribofilm }=\text { detected: } \\
\text { The thickness of the tribofilm is lower than } \\
2 \mathrm{~nm} \text {, as indicated by SIMS profiling. }\end{array}$ & SIMS & [13] \\
\hline DLC & $\begin{array}{l}\text { PAO, } \\
\text { GMO, } \\
\text { BO, } \\
\text { ODA }\end{array}$ & $\begin{array}{l}\text { Formation of tribofilm = detected: } \\
\text { The boundary film composed of GMO and } \\
\text { PAO was detected by TOF-SIMS analysis. }\end{array}$ & TOF-SIMS & {$[14]$} \\
\hline $\mathrm{a}-\mathrm{C}: \mathrm{H}$, ta-C & $\begin{array}{l}\text { PAO, } \\
\text { GMO }\end{array}$ & $\begin{array}{l}\text { Formation of tribofilm = not detected: } \\
\text { The antiwear tribofilm grown on steel is } \\
\text { very easy to observe, whereas on DLC } \\
\text { coatings, such a film cannot be evidenced } \\
\text { by optical microscopy. This means that } \\
\text { either there is no growth of tribofilm on } \\
\text { DLC or it is too thin to observe. }\end{array}$ & $\begin{array}{c}\text { Optical } \\
\text { microscopy }\end{array}$ & [43] \\
\hline
\end{tabular}


Table 4 shows tribofilm formation on DLC coatings with other additives. Film formation on the DLC disk occurred during the running-in process [44]. It is reported that tungsten in the transferred layer reacts with sulfur in the additive, forming lamellar $\mathrm{WS}_{2}$ tribofilms [45]. Doping a reactive material, such as tungsten, with an additive seems to be effective in tribofilm formation.

Table 4. Tribofilm formation on DLC coatings from other additives.

\begin{tabular}{|c|c|c|c|c|}
\hline $\begin{array}{c}\text { DLC coatings } \\
\text { (See } \\
\text { Nomenclature) }\end{array}$ & $\begin{array}{c}\text { Lubricants } \\
\text { (See } \\
\text { Nomenclature) }\end{array}$ & Remarks about tribofilm formation & Analysis & Reference \\
\hline DLC & $\begin{array}{l}\text { PAO, calcium } \\
\text { sulfonate }\end{array}$ & $\begin{array}{l}\text { Formation of tribofilm = detected: } \\
\text { A remarkable running-in process was } \\
\text { observed at the steel-DLC contact, and it was } \\
\text { not observed in the friction test with the "fresh } \\
\text { steel ball/rubbed DLC disk". It is concluded } \\
\text { from the results that the film formation on the } \\
\text { DLC disk occurred during the } \\
\text { running-in process. }\end{array}$ & ToF-SIMS & [44] \\
\hline a-C:H:WC & $\begin{array}{c}\text { PAO, sulfurized } \\
\text { olefin } \\
\text { polysulfide }\end{array}$ & $\begin{array}{l}\text { Formation of tribofilm = detected: } \\
\text { In the presence of the S-based EP (extream } \\
\text { pressure) additive, tungsten in the transferred } \\
\text { layer reacts with sulfur in the additive, } \\
\text { forming lamellar } \mathrm{WS}_{2} \text { tribofilms on steel } \\
\text { counter-face or the revealed steel substrate. } \\
\text { Chemical property of tribofilm: } \\
\text { These tribofilms have tribological properties } \\
\text { similar to } \mathrm{MoS}_{2} \text {. } \\
\text { Performance of tribofilm = positive: } \\
\text { Depending on the additive concentration, the } \\
\text { tribofilms may increase in thickness and } \\
\text { density, thus providing conditions for } \\
\text { low-friction behavior. }\end{array}$ & SEM & [45] \\
\hline DLC & $\begin{array}{c}\mathrm{PAO} \\
{[\mathrm{BMP}][\mathrm{FAP}]}\end{array}$ & $\begin{array}{l}\text { Formation of tribofilm = detected: } \\
\text { During the friction tests, the high pressure and } \\
\text { temperature conditions in the contact caused } \\
\text { the reaction of the FAP-anion with the DLC } \\
\text { surface to a high extent (up to } 80 \% \text { ), forming } \\
\text { a tribofilm. } \\
\text { [BMP][FAP] also reacted with the surface } \\
\text { outside the wear scar, forming a tribofilm. } \\
\text { Performance of tribofilm = positive: } \\
\text { This tribofilm significantly improved the } \\
\text { antifriction behavior, even under severe loads. } \\
\text { Chemical property of tribofilm: } \\
\text { This tribofilm contained between } 20 \% \text { and } \\
40 \% \text { of the total fluorine atoms. }\end{array}$ & XPS & [46] \\
\hline
\end{tabular}


Table 4. Cont.

\begin{tabular}{|c|c|c|c|c|}
\hline DLC:Cr & $\begin{array}{c}\text { PAO, } \\
\text { ZnDTP, } \\
{[\mathrm{BMP}][\mathrm{FAP}]} \\
{[\text { (NEMM)MOE }]} \\
{[\mathrm{FAP}]}\end{array}$ & $\begin{array}{l}\text { Formation of tribofilm = detected: } \\
\text { SEM images and XPS analysis indicated that } \\
\text { the tribological improvement was due to } \\
\text { additive-surface interactions, which promoted } \\
\text { the formation of a tribofilm. }\end{array}$ & $\begin{array}{c}\text { SEM, } \\
\text { XPS }\end{array}$ & [47] \\
\hline C:H:WC & $\begin{array}{c}\text { PAO, } \\
\text { Nitrogen sulfur, } \\
\text { Amine } \\
\text { phosphate, } \\
\text { Phosphate ester, } \\
\text { Sulfurized } \\
\text { isobutylene } \\
\end{array}$ & $\begin{array}{l}\text { Formation of tribofilm = detected: } \\
\text { Additive-WC-DLC interactions formed } \\
\text { tribofilms composed of carbon- and } \\
\text { sulfur-rich species and a lower concentration } \\
\text { of oxygen, nitrogen and phosphorous } \\
\text { compared to additive-steel interactions. }\end{array}$ & XPS & [48] \\
\hline $\mathrm{a}-\mathrm{C}: \mathrm{H}: \mathrm{Ti}$ & $\begin{array}{c}\text { PFPE, } \\
\text { 1-alkyl-3- } \\
\text { octylimidazolium } \\
\text { hexafluorophosp } \\
\text { hate (L-P801) } \\
\end{array}$ & $\begin{array}{l}\text { Formation of tribofilm = detected: } \\
\text { XPS analyses indicated that tribochemical } \\
\text { films and chemical adsorption films were } \\
\text { formed on the worn surface of Ti-DLC } \\
\text { coatings under L-P801 lubrication conditions. }\end{array}$ & $\begin{array}{c}\text { SEM, } \\
\text { XPS }\end{array}$ & [49] \\
\hline DLC & $\begin{array}{c}\mathrm{PAO}, \\
{[(\mathrm{NEMM}) \mathrm{MOE}]} \\
{[\mathrm{FAP}]}\end{array}$ & $\begin{array}{l}\text { Formation of tribofilm = detected: } \\
\text { Performance of tribofilm = negative: } \\
\text { The ionic liquid does not react with the DLC } \\
\text { surface unless there is an increase in the } \\
\text { loading conditions. }\end{array}$ & $\begin{array}{c}\text { SEM, } \\
\text { XPS }\end{array}$ & {$[50]$} \\
\hline
\end{tabular}

Ionic liquid reacted with the surface outside the wear scar then a tribofilm was formed on the outside surface [46]. Ionic liquid formed a tribofilm with wear resistance on the normal DLC. This means ionic liquid has a strong potential to adhere to the DLC surface.

Furthermore, due to the strong interaction of their components through the Coulomb force, ionic liquids have higher thermal stability, no flammability and low volatility [51-55]. SEM images and XPS analysis indicated that the tribological improvement was due to additive-surface interactions, which promoted the formation of a tribofilm [47]. Ionic liquids are expected to be greener alternatives to conventional additives.

\subsection{Formation of Tribofilm and Properties}

The protective film made on the DLC surface can be characterized as shown in Figure 3. Layer by layer protective film is shown schematically in Figure 3a, and lateral heterogeneous protective film is shown schematically in Figure 3b.

Such as layer by layer protective film was observed when DLC was lubricated with ZnDTP-containing lubricants [27]. The layers consist of phosphate on the DLC coating, which is followed by sulfides and thiophosphates. ZnDTP also makes a layer by layer protective film on the steel surface. However, the thickness of the layer on DLC is thinner than the layer on the steel surface. Furthermore, the contents of these layers are different. The layer on the DLC did not have wear resistance. Especially, the outer layer consisting of sulfides and thiophosphates is easily removed by 
wear. If a wear-resistant protective layer were needed, the reactiveness of DLC with the layer should be improved. Doping reactive materials in DLC is an effective method [27].

Such as lateral heterogeneous protective film was observed on a tungsten carbide-doped DLC surface [48]. The film consists of multiple materials, such as tungsten sulfide, tungsten carbide, oxides and organic-sulfur, depending on the contents of the lubricants. When $\mathrm{WC}$ or $\mathrm{WS}_{2}$ is formed on the DLC:WC surface, an excellent tribological property was observed. On the other hand, when oxides or organic sulfide is formed on the DLC:WC surface, poor tribological properties were observed.

Mono-molecular layer adsorption on the DLC surface is shown schematically in Figure 4 [13]. The thickness of this tribofilm is thinner than $2 \mathrm{~nm}$ [13]. A low friction coefficient of 0.03 was obtained by this tribofilm formed on ta-C. It was supposed that degradated GMO produced $\mathrm{OH}$ species on carbon surface [13], especially by the reaction with the carbon radical. This tribofilm was observed by TOF-SIMS analysis.

Figure 3. (a) Layer by layer protective film on a DLC surface; (b) Lateral heterogeneous protective film on a DLC surface.

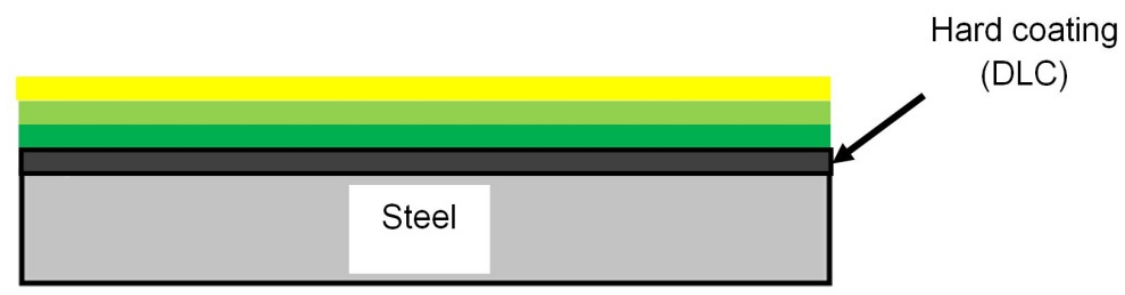

(a)

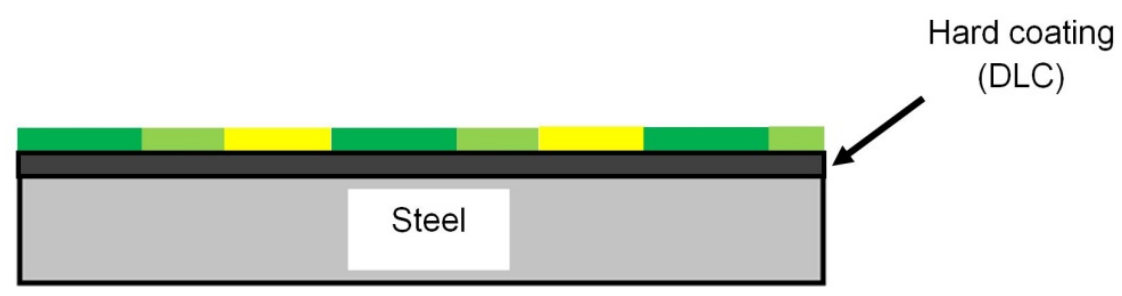

(b)

Figure 4. Mono-molecular layer absorption on the DLC surface.

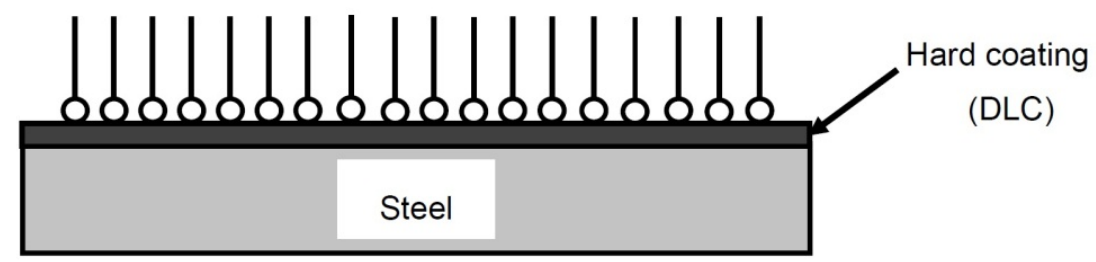

\subsection{The Effect of Tribofilm Formation on the Friction Coefficient and Wear Rate}

Figure 5 indicates the wear rate and friction coefficient reported by different researchers. Table 5 shows the experimental conditions and results of tribofilm formation in each of these references. 
Figure 5. Friction coefficient and wear rate data from different published studies. (See the tribotester and test conditions in Table 5. The reference numbers with a red circle mean that tribofilm formation was confirmed.)

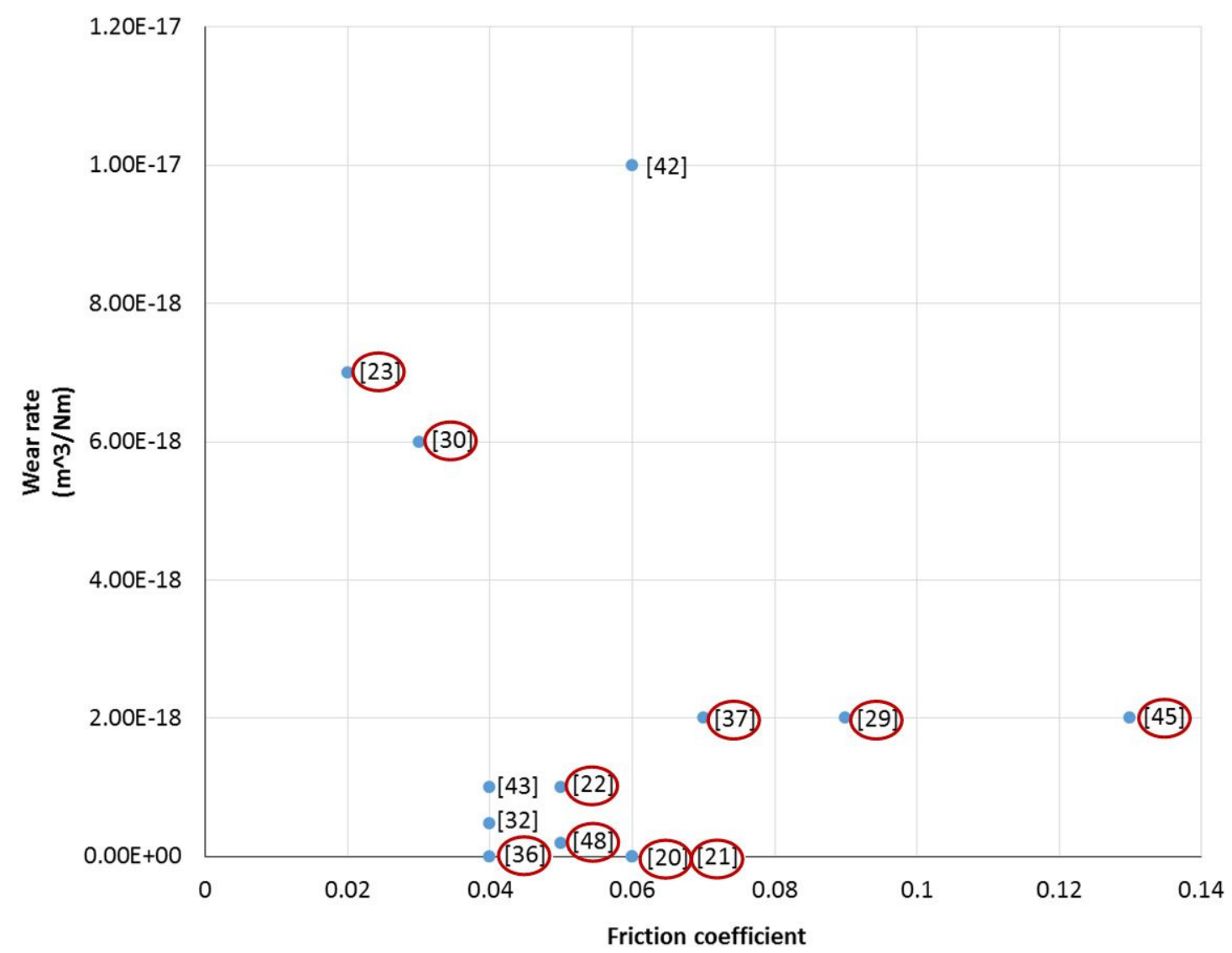

Tribofilm seems to be effective in reducing both friction and wear in [20-22,29,36,37,48]. When compared with [42], tribofilm seems to be effective in reducing the wear rate. However, a tribofilm in $[23,30]$ did not reduce the wear rate. This tribofilm was made from ZnDTP on a DLC surface. The ZnDTP tribofilm is easily removed, because the tribofilm is weakly associated with the DLC surface.

Another tribofilm did not reduce the friction coefficient [45]. This tribofilm was made from organic sulfide on a-C:H:WC surface. The DLC:WC surface is reactive to additives. A well-formed thick tribofilm could make the friction coefficient higher.

While comparing these results, it is important to keep in mind that the tribotester and test conditions, e.g., contact pressure, velocity and temperature, differ and can influence the friction coefficient and wear rate. 
Table 5. Experimental conditions and results of tribofilm formation for each reference.

\begin{tabular}{|c|c|c|c|c|c|}
\hline $\begin{array}{c}\text { DLC coatings } \\
\text { (See Nomenclature) }\end{array}$ & $\begin{array}{c}\text { Lubricants } \\
\text { (See Nomenclature) }\end{array}$ & Tribo tester & $\begin{array}{c}\text { Test } \\
\text { conditions } \\
\end{array}$ & $\begin{array}{l}\text { Tribofilm } \\
\text { formation }\end{array}$ & Reference \\
\hline \multirow{2}{*}{$\begin{array}{c}\mathrm{a}-\mathrm{C} \\
\mathrm{a}-\mathrm{C}: \mathrm{H}, \\
\mathrm{a}-\mathrm{C}: \mathrm{H}: \mathrm{W}\end{array}$} & \multirow{2}{*}{$\begin{array}{l}\text { API Group III oil, } \\
\text { ZnDTP }\end{array}$} & $\begin{array}{l}\text { Friction tests: } \\
\text { rotating, ball } \\
\text { on disk }\end{array}$ & $\begin{array}{c}1 \mathrm{GPa} \\
0.1 \mathrm{~m} / \mathrm{s} \\
100^{\circ} \mathrm{C}\end{array}$ & \multirow{2}{*}{ Detected } & \multirow{2}{*}[20]{} \\
\hline & & $\begin{array}{l}\text { Wear tests: } \\
\text { reciprocating, } \\
\text { ball on disk }\end{array}$ & $\begin{array}{c}1 \mathrm{GPa}, \\
0.08 \mathrm{~m} / \mathrm{s} \\
100^{\circ} \mathrm{C} \\
\end{array}$ & & \\
\hline \multirow{2}{*}{$\begin{array}{c}\text { a-C, a-C:H, } \\
\text { ta-C, } \\
\text { DLC:W, DLC:WC, } \\
\text { DLC:Si }\end{array}$} & \multirow{2}{*}{$\begin{array}{l}\text { API Group III oil, } \\
\text { ZnDTP }\end{array}$} & $\begin{array}{l}\text { Friction tests: } \\
\text { rotating, } \\
\text { ball on disk }\end{array}$ & $\begin{array}{c}0.95 \mathrm{GPa}, \\
0.1 \mathrm{~m} / \mathrm{s} \\
100{ }^{\circ} \mathrm{C} \\
\end{array}$ & \multirow{2}{*}{ Detected } & \multirow{2}{*}[21]{} \\
\hline & & $\begin{array}{l}\text { Wear tests: } \\
\text { reciprocating, } \\
\text { ball on disk }\end{array}$ & $\begin{array}{c}0.95 \mathrm{GPa} \\
0.08 \mathrm{~m} / \mathrm{s} \\
100{ }^{\circ} \mathrm{C}\end{array}$ & & \\
\hline $\begin{array}{c}\text { a-C, } \\
\text { a-C:H, } \\
\text { C:H:Ti }\end{array}$ & $\begin{array}{c}\text { PAO, } \\
\text { ZnDTP, } \\
\text { MoDTC }\end{array}$ & $\begin{array}{l}\text { reciprocating, } \\
\text { cylinder on disk }\end{array}$ & $\begin{array}{c}0.6 \mathrm{GPa} \\
0.2 \mathrm{~m} / \mathrm{s} \\
100^{\circ} \mathrm{C}\end{array}$ & Detected & [22] \\
\hline ta-C & $\begin{array}{l}\text { PAO, } \\
\text { ZnDTP }\end{array}$ & $\begin{array}{l}\text { rotating, cylinder } \\
\text { on disk }\end{array}$ & $\begin{array}{c}0.15 \mathrm{GPa} \\
0.1 \mathrm{~m} / \mathrm{s} \\
80^{\circ} \mathrm{C} \\
\end{array}$ & Detected & [23] \\
\hline $\mathrm{a}-\mathrm{C}$ & $\begin{array}{c}\text { PAO, } \\
\text { ZnDTP, } \\
\text { MoDTC, } \\
\text { MT } \\
\end{array}$ & $\begin{array}{l}\text { reciprocating, } \\
\text { pin on disk }\end{array}$ & $\begin{array}{c}0.7 \mathrm{GPa} \\
0.03 \mathrm{~m} / \mathrm{s} \\
100{ }^{\circ} \mathrm{C}\end{array}$ & Detected & [29] \\
\hline $\mathrm{a}-\mathrm{C}: \mathrm{H}$ & $\begin{array}{l}\text { PAO, } \\
\text { ZnDTP, } \\
\text { MoDTC }\end{array}$ & $\begin{array}{l}\text { reciprocating, } \\
\text { pin on disk }\end{array}$ & $\begin{array}{c}0.7 \mathrm{GPa} \\
0.02 \mathrm{~m} / \mathrm{s} \\
100^{\circ} \mathrm{C}\end{array}$ & Detected & [30] \\
\hline DLC:H & $\begin{array}{l}\text { PAO, ZnDTP, } \\
\text { MoDTC }\end{array}$ & $\begin{array}{l}\text { reciprocating, } \\
\text { pin on disk }\end{array}$ & $\begin{array}{c}0.6 \mathrm{GPa} \\
0.015 \mathrm{~m} / \mathrm{s} \\
100{ }^{\circ} \mathrm{C} \\
\end{array}$ & $\begin{array}{c}\text { Not } \\
\text { detected }\end{array}$ & [32] \\
\hline \multirow{2}{*}{$\begin{array}{c}\text { a-C, a-C:H, } \\
\text { a-C:H:W, } \\
\text { a-C:H:WC, } \\
\text { ta-C, ta-C:H, DLC:Si }\end{array}$} & \multirow{2}{*}{$\begin{array}{l}\text { API Group III oil, } \\
\text { MoDTC }\end{array}$} & $\begin{array}{l}\text { Friction tests: } \\
\text { rotating, } \\
\text { ball on disk }\end{array}$ & $\begin{array}{c}1 \mathrm{GPa}, \\
0.1 \mathrm{~m} / \mathrm{s} \\
100^{\circ} \mathrm{C}\end{array}$ & \multirow{2}{*}{ Detected } & \multirow{2}{*}[36]{} \\
\hline & & $\begin{array}{l}\text { Wear tests: } \\
\text { reciprocating, } \\
\text { ball on disk }\end{array}$ & $\begin{array}{c}1 \mathrm{GPa} \\
0.08 \mathrm{~m} / \mathrm{s} \\
100{ }^{\circ} \mathrm{C} \\
\end{array}$ & & \\
\hline a-C:H:W & $\begin{array}{l}\text { PAO, } \\
\text { GMO, } \\
\text { ZnDTP, } \\
\text { MoDTC }\end{array}$ & $\begin{array}{l}\text { reciprocating, } \\
\text { pin on disk }\end{array}$ & $\begin{array}{c}0.7 \mathrm{GPa} \\
0.25 \mathrm{~m} / \mathrm{s} \\
100{ }^{\circ} \mathrm{C}\end{array}$ & Detected & {$[37]$} \\
\hline
\end{tabular}


Table 5. Cont.

\begin{tabular}{|c|c|c|c|c|c|}
\hline $\mathrm{a}-\mathrm{C}: \mathrm{H}$ & $\begin{array}{l}\text { fully formulated oil, } \\
\text { ZnDTP, MoDTC }\end{array}$ & $\begin{array}{l}\text { reciprocating, } \\
\text { pin on disk }\end{array}$ & $\begin{array}{c}0.7 \mathrm{GPa} \\
0.02 \mathrm{~m} / \mathrm{s} \\
100^{\circ} \mathrm{C}\end{array}$ & $\begin{array}{c}\text { Not } \\
\text { detected }\end{array}$ & [42] \\
\hline $\begin{array}{l}\text { a-C:H, } \\
\text { ta-C }\end{array}$ & PAO, GMO & $\begin{array}{c}\text { reciprocating, } \\
\text { ball on disk }\end{array}$ & $\begin{array}{c}0.54 \mathrm{GPa} \\
0.035 \mathrm{~m} / \mathrm{s} \\
110^{\circ} \mathrm{C} \\
\end{array}$ & $\begin{array}{c}\text { Not } \\
\text { detected }\end{array}$ & [43] \\
\hline $\mathrm{a}-\mathrm{C}: \mathrm{H}: \mathrm{WC}$ & $\begin{array}{l}\text { PAO, sulfurized } \\
\text { olefin polysulfide }\end{array}$ & $\begin{array}{l}\text { reciprocating, } \\
\text { ball on disk }\end{array}$ & $\begin{array}{c}1.5 \mathrm{GPa} \\
0.02 \mathrm{~m} / \mathrm{s} \\
50^{\circ} \mathrm{C} \\
\end{array}$ & Detected & [45] \\
\hline $\mathrm{H}: \mathrm{WC}$ & $\begin{array}{l}\text { PAO, nitrogen sulfur, } \\
\text { amine phosphate, } \\
\text { phosphate ester, } \\
\text { sulfurized } \\
\text { isobutylene }\end{array}$ & $\begin{array}{l}\text { rotating, } \\
\text { ball on disk }\end{array}$ & $\begin{array}{c}1.5 \mathrm{GPa} \\
1.02 \mathrm{~m} / \mathrm{s} \\
80{ }^{\circ} \mathrm{C}\end{array}$ & Detected & [48] \\
\hline
\end{tabular}

\section{Conclusions}

In this review, different types of DLCs and additive combinations that are favorable in the formation of tribofilm on DLC have been discussed.

Doped material in DLC has the potential to improve tribofilm formation. Several elements, such as $\mathrm{Si}, \mathrm{W}$ and Ti, are available for doping. Selecting reactive materials with conventional additives, such as $\mathrm{W}$, is a possibility for enhancing the tribofilm formation on the DLC surface. However, too much W can cause graphitization of the DLC surface. It is important to keep an appropriate amount of tungsten.

Further, the film formation on the DLC surface can also be improved through the use of new (different) lubricant formulations. A number of reactive additives with DLC may be included in the new type of lubricants. Ionic liquids are one of the candidates for DLC lubrication.

An additive combination should take care of the film formation on the DLC surface. Some additives inhibit tribofilm formation, whereas others may promote film formation.

The possibility of achieving low friction and low wear simultaneously by a tribofilm formed on a DLC coating has also been discussed. Barring few exceptions, almost all tribofilms seem to be effective in reducing the friction coefficient and wear.

Finally, a hybrid lubrication tribofilm consisting of DLC and lubricants has the potential for not only reducing friction and wear, but also imparting an environmentally friendly property. Further research in this hybrid tribofilm aspect is necessary for high performance and environmentally benign tribological systems.

\section{Acknowledgments}

The funding from Kempe Foundation of Sweden (Kempestiftelserna) for this post-doctoral research project "Hybrid Lubrication" is gratefully acknowledged.

\section{Conflicts of Interest}

The authors declare no conflict of interest. 


\section{References}

1. Jost, H.P. Tribology: How a word was coined 40 years ago. Tribol. Lubr. Technol. 2006, 3, 24-28.

2. Jost, H.P. Tribology-Origin and future. Wear 1990, 136, 1-17.

3. Czichos, H. Tribology: A Systems Approach to the Science and Technology of Friction, Lubrication and Wear; Elsevier Scientific Publishing Company: Amsterdam, The Netherlands, 1978; pp. 130-131.

4. Roegiers, M.; Zhmud, B. Tribological performance of ionised vegetable oils as lubricity and fatty oiliness additives in lubricants and fuels. Lubr. Sci. 2009, 21, 169-182.

5. Zhmud, B. Developing energy-efficient lubricants and coatings for automotive applications. Tribol. Lubr. Technol. 2011, 9, 42-49.

6. Spikes, H. The history and mechanisms of ZDDP. Tribol. Lett. 2004, 17, 469-489.

7. Nicholls, M.A.; Do, T.; Norton, P.R.; Kasrai, M.; Bancroft, G.M. Review of the lubrication of metallic surfaces by zinc dialkyl-dithiophosphates. Tribol. Int. 2005, 38, 15-39.

8. Minami, I.; Mori, H.; Katoh, A.; Marukane, Y.; Kohzu, Y. Proposal of Lubricant Maintenance by Monitoring Peroxide Value. J. Jpn. Pet. Inst. 2009, 52, 351-356.

9. Whitby, R.D. Competition for metal surfaces. Tribol. Lubr. Technol. 2013, 9, 88.

10. Anastas, P.T.; Warner, J.C. Green Chemistry: Theory and Practice; Oxford University Press: New York, NY, USA, 1998; pp. 30.

11. Bartz, W.J. Lubricants and the environment. Tribol. Int. 1998, 31, 35-47.

12. Spikes, H. Low- and zero-sulphated ash, phosphorus and sulphur anti-wear additives for engine oils. Lubr. Sci. 2008, 20, 103-136.

13. Kano, M.; Yasuda, Y.; Okamoto, Y.; Mabuchi, Y.; Hamada, T.; Ueno, T.; Ye, J.; Konishi, S.; Takeshima, S.; Martine, J.M.; et al. Ultralow friction of DLC in presence of glycerol mono-oleate (GMO). Tribol. Lett. 2005, 18, 245-251.

14. Minami, I.; Kubo, T.; Nanao, H.; Mori, S. Investigation of tribo-chemistry by means of stable isotopic tracers, Part 2: Lubrication mechanism of friction modifiers on diamond-like carbon. Tribol. Trans. 2007, 50, 477-487.

15. Erdemir, A.; Donnet, C. Tribology of diamond-like carbon films: Recent progress and future prospects. J. Phys. D 2006, 39, 311-327.

16. Charitidis, C.A.; Koumoulos, E.P.; Dragatogiannis, D.A. Nanotribological Behavior of Carbon Based Thin Films: Friction and Lubricity Mechanisms at the Nanoscale. Lubricants 2013, 1, 22-47.

17. Erdemir, A. Friction and wear of diamond and diamond-like carbon films. J. Eng. Tribol. 2002, 216, 387-400.

18. Erdemir, A. Genesis of superlow friction and wear in diamondlike carbon films. Tribol. Int. 2004, 37, 1005-1012.

19. Minami, I.; He, X.; Prakash, B. Coating-lubricant combination for improving tribo-system performance. Lubr. Sci., in press. 
20. Vengudusamy, B.; Green, J.H.; Lamb, G.D.; Spikes, H.A. Influence of hydrogen and tungsten concentration on the tribological properties of DLC/DLC contacts with ZDDP. Wear 2013, 298-299, 109-119.

21. Vengudusamy, B.; Green, J.H.; Lamb, G.D.; Spikes, H.A. Tribological properties of tribofilms formed from ZDDP in DLC/DLC and DLC/steel contacts. Tribol. Int. 2011, 44, 165-174.

22. De Barros'Bouchet, M.I.; Martin, J.M.; Le-Mogne, T.; Vacher, B. Boundary lubrication mechanisms of carbon coatings by MoDTC and ZDDP additives. Tribol. Int. 2005, 38, 257-264.

23. Tasdemir, H.A.; Wakayama, M.; Tokoroyama, T.; Kousaka, H.; Umehara, N.; Mabuchi, Y.; Higuchi, T. Wear behavior of tetrahedral amorphous diamond-like carbon (ta-C DLC) in additive containing lubricants. Wear 2013, 307, 1-9.

24. Equey, S.; Roos, S.; Mueller, U.; Hauert, R.; Spencer, N.D.; Crockett, R. Tribofilm formation from ZnDTP on diamond-like carbon. Wear 2008, 264, 316-321.

25. Tasdemir, H.A.; Wakayama, M.; Tokoroyama, T.; Kousaka, H.; Umehara, N.; Mabuchi, Y.; Higuchi, T. Ultra-low friction of tetrahedral amorphous diamond-like carbon (ta-C DLC) under boundary lubrication in polyalpha-olefin (PAO) with additives. Tribol. Int. 2013, 65, 286-294.

26. Equey, S.; Roos, S.; Mueller, U.; Hauert, R.; Spencer, N.D.; Crockett, R. Reactions of zinc-free anti-wear additives in DLC/DLC and steel/steel contacts. Tribol. Int. 2008, 41, 1090-1096.

27. Vengudusamy, B.; Green, J.H.; Lamb, G.D.; Spikes, H.A. Durability of ZDDP Tribofilms Formed in DLC/DLC Contacts. Tribol. Lett. 2013, 51, 469-478.

28. Morina, A.; Zhao, H.; Mosselmans, J.F.W. In-situ reflection-XANES study of ZDDP and MoDTC lubricant films formed on steel and diamond like carbon (DLC) surfaces. Appl. Surf. Sci. 2014, 297, 167-175.

29. Haque, T.; Morina, A.; Neville, A. Influence of friction modifier and antiwear additives on the tribological performance of a non-hydrogenated DLC coating. Surf. Coat. Technol. 2010, 204, 4001-4011.

30. Kosarieh, S.; Morina, A.; Lainé, E.; Flemming, J.; Neville, A. Tribological performance and tribochemical processes in a DLC/steel system when lubricated in a fully formulated oil and base oil. Surf. Coat. Technol. 2013, 217, 1-12.

31. Mistry, K.K.; Morina, A.; Neville, A. A tribochemical evaluation of a WC-DLC coating in EP lubrication conditions. Wear 2011, 271, 1739-1744.

32. Haque, T.; Morina, A.; Neville, A.; Kapadia, R.; Arrowsmith, S. Effect of oil additives on the durability of hydrogenated DLC coating under boundary lubrication conditions. Wear 2009, 266, $147-157$.

33. Kano, M.; Yasuda, Y. The Effect of ZDDP and MoDTC additives in engine oil on the friction properties of DLC-coated and steel cam followers. Lubr. Sci. 2004, 17, 95-103.

34. Haque, T.; Morina, A.; Neville, A. Tribological performance evaluation of a hydrogenated diamond-like carbon coating in sliding/rolling contact-Effect of lubricant additives. J. Eng. Tribol. 2011, 225, 393-405.

35. Topolovec-Miklozic, K.; Lockwood, F.; Spikes, H. Behaviour of boundary lubricating additives on DLC coatings. Wear 2008, 265, 1893-1901.

36. Vengudusamy, B.; Green, J.H.; Lamb, G.D.; Spikes, H.A. Behaviour of MoDTC in DLC/DLC and DLC/steel contacts. Tribol. Int. 2012, 54, 68-76. 
37. Yang, L.; Neville, A.; Brown, A.; Ransom, P.; Morina, A. Friction reduction mechanisms in boundary lubricated W-doped DLC coatings. Tribol. Int. 2014, 70, 26-33.

38. Zhiqiang, F.; Jian, S.; Chengbiao, W.; Wei, Z.; Wen, Y.; Zhijian, P.; Xiang, Y.; Songsheng, L.; Mingjiang, D. Tribological performance of DLC coatings deposited by ion beam deposition under dry friction and oil lubricated conditions. Vacuum 2013, 94, 14-18.

39. Yue, W.; Liu, C.; Fu, Z.; Wang, C.; Huang, H.; Liu, J. Synergistic effects between sulfurized W-DLC coating and MoDTC lubricating additive for improvement of tribological performance. Tribol. Int. 2013, 62, 117-123.

40. Keunecke, M.; Bewilogua, K.; Becker, J.; Gies, A.; Grischke, M. CrC/a-C:H coatings for highly loaded, low friction applications under formulated oil lubrication. Surf. Coat. Technol. 2012, 207, 270-278.

41. Sugimoto, I.; Honda, F.; Inoue, K. Analysis of wear behavior and graphitization of hydrogenated DLC under boundary lubricant with MoDTC. Wear 2013, 305, 124-128.

42. Kosarieh, S.; Morina, A.; Laine, E.; Flemming, J.; Neville, A. The effect of MoDTC-type friction modifier on the wear performance of a hydrogenated DLC coating. Wear 2013, 302, 890-898.

43. Héau, C.; Ould, C.; Maurin-Perrier, P. Tribological behaviour analysis of hydrogenated and nonhydrogenated DLC lubricated by oils with and without additives. Lubr. Sci. 2013, 25, $275-285$.

44. Kubo, T.; Fujiwara, S.; Nanao, H.; Minami, I.; Mori, S. Boundary film formation from overbased calcium sulfonate additives during running-in process of steel-DLC contact. Wear 2008, 265, 461-467.

45. Podgornik, B.; Hren, D.; Vizintin, J.; Jacobson, S.; Stavlid, N.; Hogmark, S. Combination of DLC coatings and EP additives for improved tribological behaviour of boundary lubricated surfaces. Wear 2006, 261, 32-40.

46. González, R.; Battez, A.H.; Blanco, D.; Viesca, J.L.; Fernández-González, A. Lubrication of TiN, CrN and DLC PVD Coatings with 1-butyl-1-methylpyrrolidinium tris(pentafluoroethyl) trifluorophosphate. Tribol. Lett. 2010, 40, 269-277.

47. González, R.; Battez, A.H.; Viesca, J.L.; Higuera-Garrido, A.; Fernández-gonzá lez, A. Lubrication of DLC Coatings with Two Tris(pentafluoroethyl)trifluorophosphate Anion-Based Ionic Liquids. Tribol. Trans. 2013, 56, 887-895.

48. Mistry, K.K.; Morina, A.; Erdemir, A.; Neville, A. Extreme pressure lubricant additives interacting on the surface of steel- and tungsten carbide-doped diamond-like carbon. Tribol. Trans. 2013, 56, 623-629.

49. Feng, X.; Xia, Y. Tribological properties of Ti-doped DLC coatings under ionic liquids lubricated conditions. Appl. Surf. Sci. 2012, 258, 2433-2438.

50. Battez, A.H.; González, R.; Viesca, J.L.; Fernández-González, A.; Hadfield, M. Lubrication of PVD coatings with ethyl-dimethyl-2-methoxyethylammonium tris(pentafluoroethyl)trifluorophosphate. Tribol. Int. 2013, 58, 71-78.

51. Minami, I. Ionic liquids in tribology. Molecules 2009, 14, 2286-2305.

52. Bermúdez, M.; Jiménez, A.; Sanes, J.; Carrión, F. Ionic Liquids as Advanced Lubricant Fluids. Molecules 2009, 14, 2888-2908. 
53. Zhou, F.; Liang, Y.; Liu, W. Ionic liquid lubricants: Designed chemistry for engineering applications. Chem. Soc. Rev. 2009, 38, 2590-2599.

54. Palacio, M.; Bhushan, B. A Review of Ionic Liquids for Green Molecular Lubrication in Nanotechnology. Tribol. Lett. 2010, 40, 247-268.

55. Somers, A.E.; Howlett, P.C.; MacFarlane, D.R.; Forsyth, M. A Review of Ionic Liquid Lubricants. Lubricants 2013, 1, 3-21.

(C) 2014 by the authors; licensee MDPI, Basel, Switzerland. This article is an open access article distributed under the terms and conditions of the Creative Commons Attribution license (http://creativecommons.org/licenses/by/3.0/). 